\title{
Angst voor de dood als schade(post)
}

\author{
A. M. Overbeul LL $M^{*}$
}

1. Inleiding

Heeft u weleens een figuurlijke doodsangst uitgestaan? In dat geval bent $\mathrm{u}$ waarschijnlijk uiterst bevreesd en bezorgd geweest. ${ }^{1}$ Het is echter ook mogelijk dat u letterlijk bang bent geweest voor de dood. Wanneer deze angst is veroorzaakt door het onrechtmatig handelen van een ander, kan de vraag rijzen of uw doodsangst grond oplevert voor een schadevergoeding. In dat geval speelt de vraag of angst voor de dood te kwalificeren valt als juridische 'schade' in de zin van artikel 6:95 van het Burgerlijk Wetboek (BW). ${ }^{2}$

De redactie van TVP heeft mij gevraagd om een bijdrage te wijden aan angst voor de dood als schade(post). ${ }^{3}$ Aanleiding hiervoor is een arrest van het Franse Cour de Cassation, waarin het Hof arrest wijst over angst voor de dood (par. 2). ${ }^{4}$ Dit arrest zal in deze bijdrage (slechts) ter inspiratie dienen, waarna ik inga op angst voor de dood als schade(post) in het Nederlandse recht. Vervolgens zal ik angst als schade toespitsen op de dood, waarbij ik een onderscheid maak tussen drie verschillende situaties: het slachtoffer weet niet óf hij doodgaat, het slachtoffer heeft het ongeval - tegen de verwachting in - overleefd, en het slachtoffer weet dat hij gaat overlijden (par. 3). Afgesloten wordt met een conclusie (par. 4).
* Mw. A.M. Overheul LLM is als wetenschappelijk medewerker verbonden aan de Hoge Raad der Nederlanden.

De auteur schrijft deze bijdrage op persoonlijke titel. In deze bijdrage wordt verwezen naar een bijdrage in AV\&S die op het moment van schrijven nog niet is gepubliceerd. Deze bijdrage zal ongeveer gelijktijdig gepubliceerd worden met onderhavige bijdrage.

1. Van Dale omschrijft (figuurlijke) doodsangst als een 'grote, buitengewone angst'. Laatst geraadpleegd op 27 september 2018.

2. En om specifiek te zijn: art. 6:106 lid 1 sub b BW.

3. Ik zet post hier tussen haakjes, omdat het naar mijn mening niet duidelijk is of angst daadwerkelijk als schadepost moet worden gekwalificeerd.

4. Cass. $2^{\mathrm{e}}$ Civ., 2 februari 2017, 16-11411.

\section{Angst voor de dood: een Frans voorbeeld}

\subsection{Inleiding}

Angstschade is booming in Frankrijk. ${ }^{5}$ De angstschadevordering heeft zich al ver ontwikkeld in de Franse (cassatie)rechtspraak. Als uitgangspunt heeft te gelden dat angst onder bepaalde omstandigheden door het Cour de Cassation als schade wordt beschouwd ('préjudice d'anxiété). ${ }^{6}$ Hieraan voorafgaand is angstschade reeds erkend in de lagere Franse jurisprudentie. ${ }^{7}$ Zo kent het Cour d'Appel in Montpellier aan benadeelden die besmet vlees hebben gegeten, angstschade toe voor het mogelijk oplopen van de Creutzfeldt-Jakob-ziekte. ${ }^{8}$ Ook de mijnwerkers van Lorraine, die na een ongeval hebben vastgezeten in de mijn en daardoor zijn blootgesteld aan schadelijke stoffen, hebben recht op een vergoeding van angstscha-

5. Zo laat de overvloedige literatuur over dit onderwerp zien. Zie A.M. Overheul, Angst als juridisch relevante schade: de angstschadevordering naar Frans recht, AV\&S 2018, afl. 6, waar ik in par. 1 verwijs naar M. Bacache-Gibeili, Préjudice d'anxiété: quel domain?, Les cahiers sociaux 2015, nr. 275; B. Decrette, Préjudice d'anxiété et santé mentale, Gazette du Palais 2016, nr. 32, p. 53 e.v.; S. Gallage-Alwis \& C. Massiera, Le rejet progressif d'une indemnisation automatique et uniforme du préjudice d'anxiété, Petites Affiches 2014, nr. 73, p. 8 e.v.; L. Gamet, Le préjudice d'anxiété, Droit social 2015, nr. 1; M. Keim-Bagot, Préjudice d'anxiété: la Cour de cassation referme la boîte de Pandore, Droit social 2015, nr. 4, p. 360 e.v.; P. Jourdain, Les préjudices d'angoisse, JCP 2015, nr. 25, p. 1221-1230 (hierna: Jourdain 2015a); J. Colonna \& V. RenauxPersonnic, Le préjudice d'anxiété entre flux... et reflux?, Gazette du Palais 2015, p. 7. e.v.; A. Pando, Le préjudice d'anxiété entre spécificité et généralité, Petites Affiches 2015; W. Fraisse, Amiante: précisions au sujet du préjudice d'anxiété, Dalloz actualité 2015; W. Fraisse, Amiante: l'etendue de l'indemnisation pour préjudice d'anxiété, Dalloz actualité 2016; J. Icard, Délimitation des créanciers d'indemnisation du préjudice d'anxiété, Les cahiers sociaux 2015; A. Guégan-Lécuyer, La consécration du droit à réparation d'un préjudice spécifique d'anxiété globalisé au profit des salariés exposés à l'amiante, Recueil Dalloz 2013, p. 2954 e.v.; en P. Jourdain, Préjudice spécifique d'anxiété des travailleurs de l'amiante et troubles dans les conditions d'existence: ces préjudices sont-ils distincts?, RTD civ. 2013, p. 844-846.

6. Zie Overheul 2018, par. 3, waar ik verwijs naar V. Wester-Ouisse, S. Taylor \& D. Fairgrieve, 'Risk and French Private Law', in: Private Law Network 2018, Cambridge: Intersentia 2018 en E. de Kezel, Asbest, gezondheid en veiligheid, Antwerpen: Intersentia 2013, p. 369.

7. Overheul 2018, par. 1, waar ik verwijs naar Cour d'Appel Lyon 11 oktober 2007, nr. 1228/07; Cour d'Appel Lyon 12 september 2012, nr. 11/08573; Cour d'Appel Lyon 19 oktober 2012, nr. 12/00859; Cour d'Appel Paris 8 oktober 2013, nr. 11/11480; Cour d'Appel Douai 31 januari 2014, nr. 13/00496; Cour d'Appel Orléans 19 maart 2015, nr. 13/04029; Cour d'Appel Orléans 4 juni 2015, nr. 14/02054; Cour d'Appel Versailles 3 maart 2016, nr. 14/02091; Cour d'Appel Amiens 8 maart 2016, nr. 15/06382; Cour d'Appel Nancy 16 september 2016, nr. 15/0092; Tribunal correctional Thonon-les-Bains 26 juni 2013, nr. 683/2013; en Conseil de prud'hommes Longwy 6 februari 2015, RJS 2015, nr. 4, 259.

8. Overheul 2018, par. 3, onder verwijzing naar Cour d'Appel Montpellier 23 september 2003, niet gepubliceerd. 
de. ${ }^{9}$ Hieronder ga ik in op de angstschadevordering in het Franse recht (par. 2.2), waarna ik inzoom op een recent arrest van het Cour de Cassation over angst voor de dood (par. 2.3).

\subsection{De angstschadevordering in het Franse recht}

Angstschade wordt door het Cour de Cassation gedefinieerd als 'une situation d'inquiétude permanente face au risque d'une déclaration à tout moment d'une maladie'. ${ }^{10}$ Het gaat om een situatie van bezorgdheid, waarin men continu geconfronteerd wordt met het risico dat zich op ieder moment een ziekte kan manifesteren. Dit rechtvaardigt volgens het Cour de Cassation een afzonderlijke vergoeding voor angstschade. ${ }^{11}$ Angstschade wordt hiermee gekwalificeerd als een aparte schadepost. Waar wij in het Nederlandse recht in beginsel geen onderscheid maken tussen verschillende schadeposten, wordt in het Franse recht een onderscheid gemaakt tussen verschillende vormen van immateriële schade. Zo kent men 'pretium doloris', 'préjudice esthétique' en 'préjudice d'agrément'. ${ }^{12}$

De meeste arresten van het Cour de Cassation gaan over angst voor asbestziekten. ${ }^{13}$ Het betreft dan werknemers die in een bedrijf hebben gewerkt waar men onrechtmatig is blootgesteld aan asbest. Gezondheidsschade is er (nog) niet, waardoor zij geen beroep kunnen doen op de beroepsziekteregeling en eventueel vervroegd met pensioen kunnen gaan. ${ }^{14}$ Aangezien hun een bijkomende vergoeding geweigerd wordt, proberen de werknemers van hun werkgever een vergoeding voor angst-

9. Overheul 2018, par. 3, onder verwijzing naar Conseil de prud'hommes Forbach 30 juni 2016, niet gepubliceerd.

10. Overheul 2018, par. 3.3, waar ik verwijs naar Cass. Soc. 11 mei 2010, nr. 09-42241; 09-42242; 09-42243; 09-42244; 09-42245; 09-42246; 09-42247; 09-42248; 09-42249; 09-42250; 09-42251; 09-42252; 09-42253; 09-42254; 09-42255; 09-42256; en 09-42257, Bull. Soc. V. 206, ETL 2010, 188. Zie hierover ook kort S. de Jongh, 'Angst en aansprakelijkheid: Kruit noch lood?', De Juristenkrant 2017, p. 16.

11. Zo overweegt het Cour de Cassation: 'qu'elle a ainsi caractérisé l'existence d'un préjudice spécifique d'anxiété'.

12. Overheul 2018, par. 2, onder verwijzing naar Jourdain 2015, p. 1.

13. Overheul 2018, par. 3.3, Cass. Soc. 11 mei 2010, nr. 09-42241; 09-42242; $09-42243 ; \quad 09-42244 ; \quad 09-42245 ; \quad 09-42246 ; \quad 09-42247$; 09-42248; 09-42249; 09-42250; 09-42251; 09-42252; 09-42253; 09-42254; 09-42255; 09-42256 en 09-42257, Bull. Soc. V. 206, ETL 2010, 188; Cass. Soc. 4 december 2012, nr. 11-26.294; Cass. Soc. 25 september 2013, nr. 12-12.110, 12-20.912, 12-12.883, 12-20.157 en 11-20.948, Bulletin V., nr. 209 en Cass. Soc. 4 april 2014, nr. 12-29.824, Bulletin V, nr. 95; Cass. Soc. 19 november 2014, ECLI:FR:CCASS: 2014:SO02051, nr. 13-19263-13-19273, Recueil Dalloz 2014, 2415; Cass. Civ. 20 november 2014, ECLI:FR:CCASS:2014:C201754, nr. 13-26693; Cass. Soc. 10 december 2014, ECLI:FR:CCASS: 2014:SO02206, nr. 13-2013; Cass. Soc. 2 juli 2014, nr. 12-29.788, D. 2014, p. 1493; Cass. Soc. 3 maart 2015, nr.13-26.175; Cass. Soc. 16 september 2015, ECLI:FR:CCAS:2015:SO01346, nr. 14-14390 (niet gepubliceerd); Cass. Soc. 27 januari 2016, ECLI:FR:CCASS:2016:SO00317, nr. 15-10640-15-10726 (niet gepubliceerd); Cass. Soc. 17 februari 2016, ECLI:FR:CCAS:2016:SO00549, nr. 15-40042 (niet gepubliceerd); Cass. Soc. 26 mei 2016, ECLI:NL:FR:CCAS:2016:SO00995, nr. 15-14723-15-14731; Cass. Soc. 22 juni 2016, ECLI:FR:CCASS: 2016:SO01282, nr. 14-21014-14-21101, Recueil Dalloz 2016, 1436.

14. Overheul 2018, par. 3.3. Hier verwijs ik naar I. Samoy, Over terechte angst, (on)terechte angstschade en onterechte angstschadefobie, NTBR 2017, afl. 1, p. 1. schade te krijgen. ${ }^{15}$ Het Cour de Cassation heeft in een van zijn arresten besloten dat angstschade veroorzaakt door de blootstelling aan asbest alléén geldt voor werknemers die tewerkgesteld zijn in een onderneming die wordt vermeld in een bij ministerieel besluit vastgestelde lijst, getiteld 'une allocation de cessation anticipée d'activité' (hierna: ACAATA). ${ }^{16}$ Op de ACAATA-lijst staan bedrijven waarvan bekend is dat in het verleden is gewerkt met asbesthoudend materiaal. De lijst is aanvankelijk opgesteld om werknemers van deze bedrijven een mogelijkheid te bieden om vervroegd met pensioen te gaan. ${ }^{17}$ Het Cour de Cassation leidt uit de lijst een vermoeden van blootstelling aan asbest af, en aan de blootstelling van asbest een vermoeden van angstschade, ${ }^{18}$ ontstaan op het moment dat de lijst is gepubliceerd. ${ }^{19}$ Nader bewijs hoeft door de benadeelden niet te worden overlegd. ${ }^{20}$ Volgens het Hof betreft vermelding op de lijst een 'présumée irréfragablement' (onweerlegbaar vermoeden), hetgeen inhoudt dat tegenbewijs niet mogelijk is. ${ }^{21} \mathrm{~A}$ contrario betekent dit dat benadeelden die aan asbest zijn blootgesteld bij een bedrijf dat niet op de lijst staat, niet in aanmerking komen voor een angstschadevordering. ${ }^{22}$ Deze vergaande lijn stuit op veel verzet in de Franse doctrine. $^{23}$

In niet-asbestgerelateerde zaken moet de angst zien op het bestaan van een bewezen wetenschappelijk risico van ernstige schade waaraan de benadeelde is blootgesteld, voordat hij voor vergoeding in aanmerking kan komen. ${ }^{24}$ Uit de jurisprudentie volgt dat het moet gaan om een bewezen risico voor ernstige schade. De aard van de normschending lijkt hierbij een rol te spelen. ${ }^{25}$ Verder moet de angst een voldoende ernstige psychische stoornis hebben veroorzaakt. ${ }^{26}$ De psychische stoornis

15. Overheul 2018, par. 3.3, onder verwijzing naar Samoy 2017, p. 1.

16. Zie Overheul 2018, par. 3.3 en verdere verwijzingen aldaar.

17. Indien er gezondheidsschade is. Zie Overheul 2018, par. 3.3 en Wet van 23 december 1998, nr. 98-1194.

18. Overheul 2018, par. 3.3, waar ik verwijs naar Cass. Soc. 3 maart 2015, nr. 13-26.175 en I. Samoy \& W. Vandenbussche, Angstschade: sleutel voor de toekomst of doos van pandora?, in: M. Kruithof (ed.), Inzichten in actueel aansprakelijkheidsrecht en verzekeringsrecht, Antwerpen: Intersentia 2018, p. 210.

19. Overheul 2018, par. 3.3, onder verwijzing naar Cass. Soc. 2 juli 2014, nr. 12-29.788, D. 2014, p. 1493.

20. Overheul 2018, par. 3.3. Ik verwijs daar naar Cass. Soc. 4 april 2014, nr. 12-29.824 en 12-29.825, Bulletin V, nr. 95 en Cass. Soc. 3 maart 2015, nr. 13-20.486 en nr. 13-20.174.

21. Overheul 2018, par. 3.3, onder verwijzing naar Cass. Soc. 3 maart 2015, nr. 13-26.175. Zie hierover Samoy \& Vandenbussche 2018, p. 230.

22. Overheul 2018, par. 3.3, waar ik verwijs naar Cass. Soc. 3 maart 2015, nr. 13-26.175.

23. Overheul 2018, par. 3.3, onder verwijzing naar Keim-Bagot 2015; Colonna \& Renaux-Personnic 2015; C. Corgas-Bernard, Amiante et préjudice d'anxiété, toujours plus!, Resp. civ. et assur. 2013, afl. 3; Gamet 2015; Jourdain 2015a; en P. Jourdain, Responsabilité civile. 1. Prejudices d'anxiété des travailleurs de l'amiante: d'étranges disparités, RTD civ. 2015, p. 393 e.v. (hierna: Jourdain 2015b).

24. Jourdain 2015a, nr. 19; V.M. Develay, 'Préjudice d'angoisse ou préjudice d'exposition', RLDC 2013, p. 103.

25. Zie par. 5.4.2 en Cour de Cassation: 'qu'elle a ainsi caractérisé l'existence d'un préjudice spécifique d'anxiété'.

26. Zo overweegt het Cour de Cassation: 'que si l'anxiété suscitée par l'exposition au risque constituait un trouble psychologique suffisamment caractérisé pour appeler une "réparation spécifique". 
moet van een bepaalde mate van zekerheid zijn en een direct gevolg zijn van de schadeveroorzakende gebeurtenis. ${ }^{27}$ Onduidelijk is wat hieronder precies wordt verstaan, maar in ieder geval lijkt de psychische stoornis niet onderbouwd te hoeven worden met medische rapporten. ${ }^{28}$ Wellicht dat een onderbouwing zich eerder laat vinden in de bewijsrechtelijke regels van het aansprakelijkheidsrecht, en dat op dit punt daarom geen vaste lijn te herkennen is. Bij de vaststelling van de omvang van de angstschadevergoeding moeten alle bijkomende problemen die een benadeelde ondervindt vanwege de langdurige aanwezigheid van de angst, worden meegenomen. ${ }^{29}$ Benadeelden hoeven zich verder niet te onderwerpen aan reguliere medische controles en onderzoeken om voor een vergoeding in aanmerking te komen. ${ }^{30}$

Met betrekking tot de omvang van de schadevergoeding in het Franse recht kan ik niet veel zeggen, daar mijn onderzoek zich met name heeft toegespitst op de Franse cassatierechtspraak. ${ }^{31}$ Met betrekking tot de lagere jurisprudentie is in de doctrine opgemerkt dat in asbestzaken één standaardbedrag wordt toegekend aan alle benadeelden. Dit standaardbedrag verschilt per gerechtshof. Zo kent het Cour d'Appel Agen een standaard-angstschadevergoeding van $€ 5.000$ toe aan benadeelden, tegenover $€ 13.000$ van het Cour d'Appel Parijs. ${ }^{32}$ Gamet en Jourdain stellen dat de standaardvergoeding indruist tegen de gedachte dat angstschade een subjectieve schadepost is, en dat de omvang van de daadwerkelijk geleden angstschade van persoon tot persoon zal verschillen. ${ }^{33}$

\subsection{Angst voor de dood}

Recent heeft het Cour de Cassation een arrest gewezen over angst voor de dood als aparte schadepost. ${ }^{34}$ Het arrest gaat over een slachtoffer van een moord waarvoor twee daders zijn veroordeeld. De (minderjarige) erfgenamen procederen in naam van het slachtoffer tegen de daders om een schadevergoeding te krijgen. In de kern gaat het om de vraag of het geestelijk letsel vóór iemands overlijden kan worden gekwalificeerd als een angstschadevordering die vererft naar de erfgenamen. ${ }^{35}$

In tweede instantie, bij het hof van appel van Amiens, krijgen de nabestaanden verschillende schadevergoedingen toegekend. Zo krijgen zij ten eerste een schadevergoeding van $€ 20.000$ vanwege het fysieke en psychische lijden dat het slachtoffer

27. Idem.

28. Jourdain 2013, tweede alinea (pagina- of randnummers ontbreken).

29. Overheul 2018, par. 5, onder verwijzing naar M. Bacache, A. GuéganLécuyer \& S. Porch-Simon, 'Dommage corporel', Recueil Dalloz 2013 , afl. 40, p. 2663-2664 en Jourdain 2013.

30. Overheul 2018, par. 5, onder verwijzing naar Cass. Soc. 4 december 2012, nr. 11-26.294.

31. En ook daar wordt de angstschadevergoeding in de regel begroot door de lagere Franse rechter, zie Gamet 2015, onder II.C.

32. Gamet 2015, onder II.C.

33. Gamet 2015, onder II.C; Jourdain 2015a, nr. 23.

34. Cass. $2^{\mathrm{e}}$ Civ., 2 februari $2017,16-11411$.

35. R. Rijnhout, Vergoeding voor (im)materiële schade na de dood: over perte d'une chance de survie en lost years, NTBR 2018/4, voetnoot 20. heeft moeten doorstaan (souffrances endurées). Het slachtoffer is op brute wijze vermoord en fysiek (en psychisch) toegetakeld: er zijn meerdere botbreuken en het slachtoffer is gewurgd. Ten tweede krijgen de nabestaanden een schadevergoeding van $€ 30.000$ omdat het slachtoffer angst heeft ervaren voor de dood. Zo heeft het slachtoffer in de laatste tien minuten van zijn leven grote ademhalingsmoeilijkheden gehad. In deze tijd moet het slachtoffer zich bewust zijn geweest van de dreigende dood, hetgeen gekwalificeerd kan worden als intens geestelijk lijden, dat volgens het hof gecompenseerd moet worden.

Het Cour de Cassation casseert deze uitspraak van het hof. Volgens het Cour de Cassation heeft het hof door onderscheid te maken tussen het fysieke en psychische lijden voor de schadeveroorzakende gebeurtenis (souffrances endurées) en de angst voor de naderende dood twee keer dezelfde schade vergoed:

'Qu'en statuant ainsi, alors que le préjudice moral lié aux souffrances psychiques et aux troubles qui y sont associés étant inclus dans le poste de préjudice temporaire des souffrances endurées, quelle que soit l'origine desdites souffrances, le préjudice lié à la conscience de sa mort prochaine, qualifié dans l'arrêt de préjudice d'angoisse de mort imminente, ne peut être indemnisé séparément, la cour d'appel a réparé deux fois le même préjudice et violé le principe susvisé; $(. . .)^{36}$

Waar het Cour de Cassation asbestslachtoffers vergaand tegemoetkomt met de vergoeding van angstschade, maakt het hier pas op de plaats. De terughoudende benadering vloeit wellicht voort uit een wens om het ontstaan van meer schadeposten te voorkomen. Verder past het arrest in de lijn van een eerder arrest van de Franse cassatierechter op 20 oktober 2016. ${ }^{37}$ In deze zaak is een slachtoffer met meerdere messteken om het leven gebracht. De echtgenoot en kinderen vorderen een vergoeding voor het verlies van de kans om door te leven. Het Cour de Cassation overweegt dat het verlies van een kans op overleven op zichzelf geen recht op vergoeding oplevert en dat alleen vergoeding hoeft te worden geboden voor iemands morele lijden vanwege het bewustzijn dat de dood nadert (souffrances endurées), ${ }^{38}$ hetgeen wij wellicht eveneens als een vorm van angstschade zouden kunnen kwalificeren. Uiteraard rijst de vraag wat wij in het Nederlandse recht met deze focus op angst kunnen.

36. Cass. 2e Civ., 2 februari 2017, 16-11411.

37. Cass. $2^{\mathrm{e}}$ Civ., 20 oktober 2016, 14-28.866. Zie Rijnhout 2018.

38. Rijnhout 2018 , p. 24 en 25 . Rijnhout schrijft verder dat de uitspraak zo uitgelegd kan worden dat het feit dat het leven wordt verkort door een onrechtmatige daad een aantasting is, maar dat vergoeding alleen hoeft te worden geboden voor schade die voortvloeit uit die aantasting. $\mathrm{Zij}$ verwijst hierbij naar P. Jourdain, Cass. Crim. 26 maart 2013, RTD Civ. 2013 , p. 615. 


\section{Angstschade naar Nederlands recht}

\subsection{Inleiding}

Hoewel angstschade in Nederland nog in de kinderschoenen staat, zijn er onder meer angstschadevorderingen ingesteld voor angst voor ziekten als aids of asbestziekten, angst voor gezondheidsaantasting door milieuvervuiling en angst voor schade aan woning en leefomgeving door aardbevingen. ${ }^{39}$ In deze gevallen waren de benadeelden van mening dat zij door het onrechtmatig gedrag van de ander, waardoor zij psychisch aangeslagen waren, recht hadden op een vergoeding van hun angstschade. Angst kan onder meer leiden tot een depressie, hetgeen op haar beurt kan resulteren in vergoeding voor materiële schade. Indien iemand ziek wordt, voorziet ons recht vanaf dat moment in een vergoeding voor immateriële en materiële schade (art. 6:95 en 6:106 BW). Het is echter de vraag of dat ook geldt voor de periode van onzekerheid - de periode waarin de benadeelde niet weet of hij ziek is geworden, maar wel angst daarvoor ervaart. ${ }^{40}$ De angstschadevordering kan hier uitkomst bieden. ${ }^{41}$

Eerder schreef ik dat er geen principiële bezwaren bestaan tegen het vergoeden van angstschade. ${ }^{42}$ Onduidelijk is echter welk gewicht toekomt aan de factor angst. Verder is onduidelijk welke voorwaarden precies aan een angstschadevordering worden gesteld. ${ }^{43}$ Anders gezegd: onduidelijk is hoe angst moet worden ingebed in ons aansprakelijkheidsrecht: betreft het een vraag van aansprakelijkheid voor geestelijk letsel (moet de angst voor de schadeveroorzaker voorzienbaar zijn?) of betreft het een vraag over schade (onder welke omstandigheden leidt angst tot vergoeding van immateriële schade?). ${ }^{44}$ Hieronder volgt een korte introductie over de angstschadevordering in het Nederlandse recht, waarbij ik stil zal staan bij verschillende aspecten die voor de angstschadevordering van belang zijn (par. 3.2). Daarna zal ik de angstschadevordering toespitsen op angst voor de dood (par. 3.3), waarbij ik zoals aangekondigd een onderscheid maak tussen drie verschillende situaties: het slachtoffer weet niet óf hij doodgaat, het slachtoffer heeft het ongeval - tegen de verwachting in - overleefd, en het slachtoffer weet dat hij gaat overlijden.

39. Rb. Leeuwarden 21 januari 1993, TvGR 1996/26; Rb. Rotterdam 25 mei 1999, ECLI:NL:RBROT:1999:AA4704; Rb. Utrecht 29 juni 1999, ECLI:NL:RBUTR:1999:AH7952, KG 1999/219; Rb. Noord-Nederland 1 maart 2017, ECLI:NL:RBNNE:2017:715, r.o. 4.4.1.

40. Zie in andere zin C.J.J.M. Stolker \& D.I. Levine, 'Aids-phobia. Schadevergoeding voor angst', NJB 1996, p. 882-891, i.h.b. p. 885.

41. A.M. Overheul, Angst als juridisch relevante schade, AV\&S 2017, afl. 5, par. 1.

42. Overheul 2017, par. 4, onder verwijzing naar M.S.A. Vegter, Vergoeding van psychisch letsel door de werkgever, Den Haag: Sdu Uitgevers 2005, p. 400.

43. Overheul 2017, par. 5.

44. Overheul 2017, par. 4. Zie A.J. Verheij, Vergoedbaarheid van angstschade, NTBR 2018/3, die in dit kader spreekt over twee varianten voor een flexibele benadering van vergoeding van angstschade, namelijk: 'A. Angstschade wordt (buiten geestelijk letsel) vergoed indien sprake is van de inbreuk op een fundamenteel recht en B. Vergoeding van angstschade (buiten geestelijk letsel) vindt plaats in geval van een ernstige normschending.'

\subsection{De angstschadevordering: het juridisch kader}

Uit de lagere jurisprudentie over angstschade ${ }^{45}$ volgt dat er in beginsel een recht op vergoeding van (angst)schade bestaat, indien een norm is geschonden die strekt ter voorkoming van lichamelijk letsel. De angst voor het letsel hoeft voor de aansprakelijke partij niet voorzienbaar te zijn geweest. ${ }^{46}$

Verheij schrijft dat voor een goed begrip van de problematiek onderscheid gemaakt dient te worden tussen het geval dat angst leidt tot geestelijk letsel, en de situatie dat angst zélf als schadepost wordt opgevoerd. ${ }^{47}$ De angstschadevordering vindt haar grondslag namelijk zowel in schendingen van de geestelijke gezondheid als in schendingen van persoonlijkheidsrechten in de zin van artikel 6:106 lid 1 sub b BW. Met betrekking tot de schending van de geestelijke gezondheid is het naar mijn mening van belang wat precies onder dit 'geestelijk letsel' wordt verstaan. Met name bestaat in de lagere jurisprudentie onduidelijkheid of sprake moet zijn van een in de psychiatrie erkend ziektebeeld, of dat voor een angstschadevordering kan worden volstaan met 'medische verklaringen' of zelfs 'de enkele vrees en angst' om ziek te worden. Mijns inziens is het de vraag of moet worden aangesloten bij het criterium van een in de psychiatrie erkend ziektebeeld. Grootste bezwaar tegen het hanteren van een dergelijk criterium is dat het aansluit bij bepaalde maatstaven die een rechtzoekende geen houvast kunnen bieden. In de praktijk kan een rechter van geval tot geval bekijken of de angst hem reëel voorkomt, of dat nadere onderbouwing middels medische documenten noodzakelijk is. Ik heb eerder geschreven dat de aard van de normschending hier een rol zou kunnen spelen.

Angst kan zoals gezegd ook worden gekwalificeerd als een inbreuk op een persoonlijkheidsrecht, om specifiek te zijn de persoonlijke levenssfeer. ${ }^{48}$ In een dergelijk geval is 'geestelijk letsel' niet vereist - de ernst van de inbreuk op het persoonlijkheidsrecht rechtvaardigt dit. Nadere onderbouwing van geestelijk letsel kan in een dergelijk geval dan ook achterwege blijven - de enkele inbreuk op het persoonlijkheidsrecht rechtvaardigt een schadevergoeding. Deze inbreuk behelst dat de angst wel van enige ernst moet zijn en dat de gevolgen van de schending van het persoonlijkheidsrecht de eiser rechtstreeks treffen. Op deze wijze kunnen benadeelden van bijvoorbeeld een (zeer) ernstige normschending, zonder dat zij daadwerkelijk geestelijk letsel ondervinden, tegemoet worden gekomen. ${ }^{49}$ Hierbij moet worden opgemerkt dat de regel van artikel 6:106 lid 1 sub b BW aan uitzondering onderhevig is wanneer sprake is van 'bijzondere ernst van de normschending en de gevolgen daarvan voor het slachtoffer'. ${ }^{50}$

45. Zie over deze lagere jurisprudentie Overheul 2017. Zie ook Verheij 2018.

46. Overheul 2017, waar ik ook verwijs naar Vegter 2005, p. 400.

47. Verheij 2018, p. 43.

48. Overheul 2017, par. 5

49. Overheul 2017, par. 5

50. HR 29 juni 2012, ECLI:NL:HR:2012:BW1519, JA 2012/147 m.nt S.D. Lindenbergh (Blauw oog). Over de reikwijdte van dit arrest bestaat in de literatuur discussie. Zie recent hierover in het kader van angstschade Verheij 2018, par. 3.1. 
Verheij heeft in dit kader twee benaderingen geschetst: een terughoudende en een flexibele. ${ }^{51}$ In de terughoudende benadering fungeert geestelijk letsel als drempelvereiste. In de flexibele benadering tekenen zich volgens hem twee varianten af, die elkaar niet uitsluiten: (1) angstschade wordt (buiten geestelijk letsel) vergoed indien sprake is van de inbreuk op een fundamenteel recht, en (2) vergoeding van angstschade (buiten geestelijk letsel) vindt plaats in geval van een ernstige normschending. ${ }^{52}$ De flexibele benadering geniet zijn voorkeur. $^{53}$

In de rechtspraak wordt in het kader van de aard van de angst met name getoetst of sprake is van een reële, gerechtvaardigde angst voor het ontstaan van een potentiële ziekte. ${ }^{54}$ De gerechtvaardigde angst moet een gevolg zijn van blootstelling aan een gevaarlijke stof of situatie. Hierbij lijkt het van belang te zijn dat de angst van een langdurige periode is. Wel moet worden opgemerkt dat in de zaken verschillende belangen spelen, en dat dientengevolge de noodzakelijke periode van angst van geval tot geval zal verschillen. Vaak gaat het om zeer ernstige (potentiële) ziekten die zich kunnen verwezenlijken. ${ }^{55}$

Eventuele predisposities van de benadeelde doen, in overeenstemming met ons schadevergoedingsrecht, geen afbreuk aan zijn recht op schadevergoeding. ${ }^{56}$ Van de benadeelde zelf wordt naar mijn mening een proactieve houding verwacht om met zijn angst om te gaan, waardoor de schade binnen de grenzen van redelijkheid zo veel mogelijk wordt beperkt. Door hulp te (blijven) zoeken van deskundigen uit de gezondheidszorg zou de angst naar verloop van tijd kunnen afnemen, waardoor de benadeelde uiteindelijk (mogelijk) geen schade meer lijdt. Wel is het mijns inziens van belang dat de predispositie niet zo ver wordt doorgevoerd dat men schade zou kunnen vorderen voor een onredelijke angst. Hiermee doel ik op een angst voor een ziekte die onmogelijk zou kunnen intreden, bijvoorbeeld omdat blootstelling hieraan nooit heeft plaatsgevonden. ${ }^{57}$

\subsection{Angstschade toegespitst op de dood}

Om angstschade toe te spitsen op de dood maak ik in beginsel gebruik van de volgende fictieve casus. Een werknemer is door onzorgvuldig handelen van zijn werkgever langdurig blootgesteld aan asbest. De werkgever is tekortgeschoten in zijn verplichting om veiligheidsmaatregelen te nemen, die zijn vereist met het oog op de gevaren van het werken met asbest. Dit verzuim heeft de kans dat de werknemer een asbestkristal zou inademen in aanmerkelijke mate verhoogd. De werkgever is hiervoor aansprakelijk (ingevolge art. 7:658 BW). De werknemer ervaart door de blootstelling angst voor de potentiële gevolgen van het inademen van de asbestvezels.

51. Verheij 2018, par. 5.1.

52. Verheij 2018, par. 5.1.

53. Voor het gehele betoog verwijs ik naar Verheij 2018, par. 5.3.

54. Overheul 2017, par. 5 .

55. Overheul 2017, par. 5.

56. Overheul 2017, par. 5.

57. Overheul 2017, par. 5, waar ik verwijs naar Vegter 2005, p. 415.
Het inademen van asbest kan verschillende uitwerkingen hebben. Zo kan het kanker aan de luchtwegen veroorzaken, bijvoorbeeld mesothelioom. Dit is een niet te genezen kankerachtige aandoening van het longvlies. Het kan ook longkanker veroorzaken, hetgeen bijna altijd onbehandelbaar is. De tijd tussen blootstelling aan asbest en het ontstaan van kanker bedraagt meestal twintig tot veertig jaar. Een andere mogelijke uitwerking van het inademen van asbestvezels is pleuraplaques. Dit zijn afwijkingen aan het longvlies die duiden op asbestblootstelling, maar die op zich niet gevaarlijk zijn. Het inademen van asbestvezels kan ook leiden tot asbestose - een stoflongziekte waardoor het moeilijk is om genoeg zuurstof binnen te krijgen. Naarmate de ziekte verder vordert, treedt er zuurstoftekort in het bloed op, hetgeen tot verhoging van de bloeddruk in de longen leidt en tot hartfalen kan leiden. Genezing van deze laatste twee ziekten is niet mogelijk. ${ }^{58}$

\subsubsection{Het slachtoffer weet niet of hij doodgaat}

Het slachtoffer in onze casus weet dat hij aan asbest is blootgesteld, maar weet niet of dit ervoor zorgt dat hij komt te overlijden. Zoals gezegd bedraagt de tijd tussen blootstelling en het ontstaan van mesothelioom of longkanker twintig tot veertig jaar. Of het slachtoffer recht heeft op een vergoeding van angstschade, hangt naar mijn mening af van een aantal omstandigheden. Om de vordering een grondslag te laten vinden in schending van de geestelijke gezondheid in de zin van artikel 6:106 lid 1 sub b BW is zoals gezegd van belang wat onder 'geestelijk letsel' moet worden verstaan. De huidige leer houdt in dat sprake moet zijn van een in de psychiatrie erkend ziektebeeld. Dit maakt de kans op vergoeding van angstschade minder groot - de enkele vrees voor het overlijden is daarmee niet genoeg, en de angst voor het overlijden zal moeten worden onderbouwd met bijvoorbeeld medische rapporten. Wanneer de angst wordt gekwalificeerd als een inbreuk op een persoonlijkheidsrecht, bijvoorbeeld de persoonlijke levenssfeer of lichamelijke integriteit, is 'geestelijk letsel' geen vereiste. De ernst van de inbreuk op het persoonlijkheidsrecht zal dit rechtvaardigen. De angst moet in dit geval wel van enige ernst zijn en de gevolgen van de schending van het persoonlijkheidsrecht moeten de eiser rechtstreeks treffen. Zoals gezegd is de regel van artikel 6:106 lid 1 sub b BW aan uitzondering onderhevig wanneer sprake is van 'bijzondere ernst van de normschending en de gevolgen daarvan voor het slachtoffer'.59 In ieder geval lijkt mij in het geval van asbest aannemelijk dat sprake is van een reële, gerechtvaardigde angst voor een potentieel overlijden op korte of langere termijn. Het kwalificeren van deze angst als een gevolg van blootstelling aan een gevaarlijke stof of situatie lijkt mij niet problematisch. Ik voorzie in eerste instantie dan ook weinig problemen om de angst voor een potentiële dood in het geval van langdurige asbestbloot-

58. Voor meer informatie, zie www.beroepsziekten.nl en www.longfonds.nl, laatst geraadpleegd op 8 oktober 2018 .

59. HR 29 juni 2012, ECLI:NL:HR:2012:BW1519, JA 2012/147 m.nt. S.D. Lindenbergh (Blauw oog). Over de reikwijdte van dit arrest bestaat in de literatuur discussie. Zie recent hierover in het kader van angstschade Verheij 2018, par. 3.1. 
stelling te kwalificeren als een inbreuk op een persoonlijkheidsrecht.

\subsubsection{Het slachtoffer overleeft, tegen de verwachting in}

De langdurige blootstelling aan asbest resulteert erin dat het slachtoffer longkanker krijgt, die tegen de verwachting in wordt genezen. De angst voor de dood ziet op de periode na blootstelling aan asbest tot het bericht dat het slachtoffer hoort dat zijn ziekte - ondanks eerder bericht - kan worden genezen. Naar mijn mening maakt deze casuspositie, voor de vraag of angst voor vergoeding in aanmerking moet komen, weinig verschil met de situatie in paragraaf 3.3.1, waarin het slachtoffer niet weet of hij komt te overlijden. Zoals gezegd bestaat er in beginsel een recht op vergoeding van (angst)scha$\mathrm{de}$, indien een norm is geschonden die strekt ter voorkoming van lichamelijk letsel. Ook zonder dat het slachtoffer overlijdt, zal de normschending blijven vaststaan. Wellicht dat de angst in dit specifieke geval heviger is, daar het slachtoffer er in eerste instantie van overtuigt was dat hij zou komen te overlijden. In dat geval zou het slachtoffer wellicht beter in staat zijn om zijn angst te onderbouwen met medische rapporten om aan te tonen dat hij 'geestelijk letsel' heeft. Maar ook indien hij dit niet kan, en er sprake moet zijn van een inbreuk op een persoonlijkheidsrecht, zie ik geen moeilijkheden wanneer het aankomt op de onderbouwing dat de angst wel van enige ernst moet zijn en dat de gevolgen van de schending van het persoonlijkheidsrecht de eiser rechtstreeks moeten treffen.

Het is echter de vraag hoe te oordelen over een geval waarvan later blijkt dat de angst ongegrond was. Verheij noemt in zijn bijdrage over de vergoeding van angstschade het voorbeeld van een verkeerde diagnose, waardoor iemand gedurende een maand in de onjuiste veronderstelling verkeert dat hij terminaal ziek is. ${ }^{60}$ Volgens Verheij is het probleem dat de betrokkene daar blijvend last van kan hebben. ${ }^{61} \mathrm{Hij}$ stelt dat veel te zeggen valt voor een genuanceerde benadering, waarin de schade niet volledig wordt toe- of afgewezen. ${ }^{62}$ Ook al is in dit geval sprake van onrechtmatig handelen, het is mijns inziens de vraag of ook in dit geval sprake is van een normschending (onjuiste informatieverstrekking) die strekt tot voorkoming van lichamelijk en/of geestelijk letsel. Wellicht dat de vergoeding van angstschade dus al stukloopt op het causaal verband of de relativiteit.

\subsubsection{Het slachtoffer weet dat hij gaat overlijden}

Indien het slachtoffer weet dat hij gaat overlijden, lijkt er naar mijn idee een reële, gerechtvaardigde angst voor de dood te kunnen bestaan, die is veroorzaakt door een normschending die ziet op het voorkomen van geestelijk letsel. Het is echter nog steeds relevant dat het slachtoffer aantoont dat hij 'geestelijk letsel' heeft, en indien dat niet zo is, dat er wordt aangetoond dat er een inbreuk is gemaakt op een persoonlijkheids-

60. Verheij 2018, p. 15.

61. Verheij 2018, p. 15, onder verwijzing naar Stolker \& Levine 1996, p. 888-889 (voetnoot 32).

62. Verheij 2018, p. 15 recht. Hoewel snel zou kunnen worden geconcludeerd dat hier sprake van is, en de ernst van de normschending dat mijns inziens ook rechtvaardigt, blijft het naar mijn mening belangrijk dat per geval wordt bekeken of schade voor vergoeding in aanmerking moet komen. Zo is het interessant om stil te staan bij de situatie dat het slachtoffer wél is blootgesteld aan asbest, weet dat hij gaat overlijden, maar daar geen angst voor heeft. In dit geval zou angstschade uiteraard niet voor vergoeding in aanmerking moeten komen. Dit klinkt logisch, maar een interessante parallel kan worden getrokken met de arresten van het Cour de Cassation over angstschade. Uit de ACAATAlijst wordt zoals gezegd een vermoeden van blootstelling aan asbest afgeleid, en aan de blootstelling van asbest een vermoeden van angstschade, ${ }^{63}$ ontstaan op het moment dat de lijst is gepubliceerd. ${ }^{64}$ Nader bewijs hoeft door de benadeelden niet te worden overlegd. ${ }^{65}$ Volgens het Hof betreft vermelding op de lijst een 'présumée irréfragablement' (onweerlegbaar vermoeden), hetgeen inhoudt dat tegenbewijs niet mogelijk is. ${ }^{66}$ Zoals gezegd betekent dit a contrario dat benadeelden die aan asbest zijn blootgesteld bij een bedrijf dat niet op de lijst staat, niet in aanmerking komen voor een angstschadevordering. ${ }^{67}$ Deze situatie lijkt mij haaks te staan op het Nederlandse beginsel van volledige schadevergoeding en daarmee ook onwenselijk voor ons recht.

Verder is het in dit licht interessant om acht te slaan op de bevindingen uit de hierboven besproken Franse rechtspraak. Zoals gezegd wordt in het Franse recht een vergoeding geboden voor iemands morele lijden vanwege het bewustzijn dat de dood nadert (souffrances endurées), ${ }^{68}$ hetgeen wij wellicht als een vorm van angstschade zouden kunnen kwalificeren. In het Franse recht wordt dit als een aparte schadepost aangeduid, terwijl wij in Nederland niet werken met dergelijke schadeposten, maar voor immateriële schade acht slaan op artikel 6:106 lid 1 sub b BW. Dit maakt het 'kopiëren' van een dergelijke schadepost naar het Nederlandse recht dan ook onwenselijk. Toch is het idee om een slachtoffer - en uiteindelijk zijn of haar nabestaanden - tegemoet te komen voor een naderende dood níét onwenselijk: angst voor de dood zou een van de hevigste angsten zijn die wij als mens kunnen ervaren.

63. Overheul 2018, par. 3.3, waar ik verwijs naar Cass. Soc. 3 maart 2015, nr 13-26.175. Zie hierover ook Samoy \& Vandenbussche 2018, p. 210.

64. Overheul 2018, par. 3.3, waar ik verwijs naar Cass. Soc. 2 juli 2014, nr. 12-29.788, D. 2014, p. 1493.

65. Overheul 2018, par. 3.3, onder verwijzing naar Cass. Soc. 4 april 2014 nr. 12-29.824 en 12-29.825, Bulletin V, nr. 95 en Cass. Soc. 3 maart 2015, nr. 13-20.486 en nr. 13-20.174.

66. Overheul 2018, par. 3.3, waar verwezen wordt naar Cass. Soc. 3 maart 2015, nr. 13-26.175. Zie hierover Samoy \& Vandenbussche 2018, p. 230.

67. Overheul 2018, par. 3.3, onder verwijzing naar Cass. Soc. 3 maart 2015, nr. 13-26.175.

68. Rijnhout 2018, p. 24 en 25 . Rijnhout schrijft verder dat de uitspraak zo uitgelegd kan worden, dat het feit dat het leven wordt verkort door een onrechtmatige daad een aantasting is, maar dat vergoeding alleen hoeft te worden geboden voor schade die voortvloeit uit die aantasting. $\mathrm{Zij}$ verwijst hierbij naar Jourdain 2013, p. 615. 


\section{Conclusie}

In deze bijdrage stond ik stil bij angst voor de dood als schade(post) in het Nederlandse recht. Hierbij werd inspiratie ontleend aan het Franse recht. In het Franse recht wordt angst voor de dood niet als een aparte schadepost gekwalificeerd, maar wel het morele lijden vanwege het bewustzijn dat de dood nadert (souffrances endurées). De immateriële schadevergoeding in het Nederlandse recht vindt haar grondslag niet in door de rechtspraak ontwikkelde schadeposten, maar in artikel 6:106 lid 1 sub b BW (schendingen van de geestelijke gezondheid en schendingen van persoonlijkheidsrechten). Of angst voor de dood voor vergoeding in aanmerking moet komen, hangt af van de omstandigheden van het geval. Hierbij kan worden opgemerkt dat deze omstandigheden mijns inziens niet verschillen van de omstandigheden waaronder normaliter angstschade wordt vergoed. Daarentegen kan wel gewicht toekomen aan het feit dat angst voor de dood een zeer hevige angst is, die mogelijk het hevigst is wanneer de benadeelde weet dat hij komt te overlijden. Dit zou een rol kunnen spelen bij de vraag of sprake is van een aantasting in de persoon, bij de kwalificatie van het geestelijk letsel of bij de begroting van de schadevergoeding. 